\title{
DUNIA BENTUKAN ORANG TUA : \\ Kajian Fenomenologi tentang Isolasi Sosial Terhadap Anak dan Pembentukan Konsep Diri Serta Karakter Anak
}

\author{
Pandan Yudhapramesti \\ Program Studi Jurnalistik FIKOM UNPAD \\ pandanpramesti@gmail.com
}

\begin{abstract}
To prevent unwanted social danger of the association of children outside the home, some parents build a specific strategy in raising children, to raise children in a social environment that is controlled parent.To limit the social pollution, parents in this category strictly limiting social affiliation or participation of children in social environments outside the home, or create social isolation of children while the formation of self-concept and character progress.

This study uses a phenomenological approach, explore the everyday experience of informants about the concept of social isolation that they do to the child, during the formation of character and self-concept of children, or as it is called Berger and Luckmann during primary socialization.

The results showed that the primary socialization period is a crucial moment in the formation of self-concept and character of a child. During this period, the social isolation and protection of the parents needs to be done so that the child can absorb the meanings and values espoused parents, without much intervention from other people. After the meanings and values of parents are fully internalized in the child, then the children are introduced to the wider social environment outside the protection of the parents. Social isolation and protection of the parents will be removed when the child has been able to take decisions in accordance with the values expected of parents and able to protect himself. This belief is making your child through primary socialization period longer than the other children, but the parents who developed this concept believe this strategy will create the self concept and character of the child becomes stronger against the influence of social pollution.
\end{abstract}

Keywords : socialization, social isolation, child

\section{PENDAHULUAN}

Kita sering mendengar ungkapan manusia adalah mahluk sosial. Karenanya, manusia selalu membutuhkan manusia lain dalam kehidupannya, atau dengan kata lain manusia harus selalu bersosialisasi.
Mungkinkah manusia hidup terisolasi tanpa sosialisasi? Beberapa berita yang dimuat oleh situs berita bereputasi tinggi seperti BBC pernah memberitakan kisah anak manusia yang dibesarkan oleh lingkungan hewan.

Fotografer Julia Fullerton Batten pernah memuat serangkaian foto 
dilengkapi dengan kisah tentang beberapa anak yang dibesarkan oleh hewan(Macdonald, 2015), seperti kisah anak bernama Oxana Malaya dari Ukraine yang pada tahun 1991 ditemukan hidup bersama anjing setelah diterlantarkan oleh kedua orang tuanya yang pemabuk, atau kisah Shamdeo, seorang anak berusia empat tahun yang ditemukan di sebuah hutan di India pada tahun 1972. Ketika ditemukan, Shamdeo sedang bermain dengan anak serigala. Ia sedang bermain dengan anak serigala. Kulitnya amat gelap, dan giginya tajam, kuku runcing, rambut kusut masai dan kapalan di telapak kaki, kedua siku dan lutut. Ia senang sekali berburu ayam, makan tanah dan gemar darah. Ia punya ikatan kuat dengan anjing. Julia Batten mengabadikan lima belas kisah serupa.

Aneka kasus tersebut dikelompokkan dalam dua kelompok kasus, yaitu kasus anak-anak yang terdampar di hutan dan kasus anak-anak yang diabaikan, ditinggalkan, atau disengsarakan di rumah, sehingga mereka merasa lebih nyaman berada di antara hewan ketimbang manusia. Dalam risetnya, seperti disebutkan BBC, Batten menyimpulkan bahwa anak-anak alam liar ini bisa mengungkapkan apa yang disembunyikan dalam masyarakat yang tampaknya beradab. Sebuah kota bisa sama kejamnya dengan hutan.

Dunia ini, termasuk kehidupan sosial di dalamnya, begitu heterogen. Dunia ini terdiri dari milyaran orang yang mengelompokkan diri dalam aneka kelompok sosial sesuai dengan minat, kepentingan, dan kemampuan masing-masing. Setiap orang juga bereaksi secara berbeda dalam dunia sosial yang harus mereka hadapi. Dunia yang heterogen ini dimaknai berbeda oleh setiap orang yang berada di dalamnya.

Banyak orang menganggap, dunia yang heterogen ini banyak mengandung bahaya sosial seperti kekerasan baik verbal maupun non verbal, tata nilai atau tindakan-tindakan yang tidak sesuai dengan nilai-nilai yang diyakini, pornografi, obat terlarang, dan lain-lain. Sering kita mendengar bahwa dunia ini sudah terbalik-balik, yang benar dikatakan salah, sedangkan yang salah dikatakan benar. Benar dan salah, baik dan buruk, bagus atau jelek, gila atau waras, semua hanya konstruksi manusia. Diantara heterogenitas tersebut, agar kita dapat beradaptasi dengan kehidupan sosial yang tepat untuk diri kita, diperlukan kemampuan untuk memilih lingkungan sosial dan mengambil keputusan yang tepat. Dibutuhkan kemampuan untuk bersosialisasi agar kita dapat menjalani kehidupan sosial yang baik.

Mungkinkah kita mengisolasi diri dari dunia sosial yang tidak kita inginkan? Mungkinkah kita mengisolasi diri dari aneka pengaruh sosial yang senantiasa menerpa diri kita, baik pengaruh yang kita sadari maupun tidak kita sadari. Jika orang dewasa saja harus menghadapi tantangan besar dalam 
proses sosialisasi dengan lingkungan sosial yang harus dihadapinya, apalagi jika tantangan tersebut itu dihadapi oleh anak-anak.

Setiap generasi memiliki tantangan zaman. Banyak orang tua merasa tidak mudah membesarkan anak karena ancaman pergaulan sosial yang berbahaya. Pada masa kini misalnya, perkembangan teknologi informasi dan komunikasi bagaikan pisau yang dapat mendatangkan manfaat sekaligus bahaya, bergantung kepada kemampuan kita menggunakannya. Orang tua sering dihadapkan pada situasi serba salah, mengizinkan penggunaan TIK berarti mendatangkan kemudahan berkomunikasi, namun sekaligus juga mendatangkan bahaya seperti masuknya ancaman pornografi, kekerasan simbolik, cyber stalking atau penguntitan siber, dan lain-lain. Merupakan tantangan besar bagi para orang tua untuk dapat membesarkan anak di tengah dunia sosial yang sungguh beragam. Untuk itulah banyak orang tua merasa harus berstrategi dalam menyiapkan anak untuk menghadapi lingkungan sosial di luar rumah, yang belum tentu sesuai dengan nilai-nilai yang mereka anut.

Untuk mengatasi kekhawatiran atau mencegah bahaya sosial yang tidak diinginkan, sekelompok orang tua memutuskan untuk membangun strategi khusus dalam membesarkan anak. Strategi yang mereka lakukan antara lain adalah memilih untuk membesarkan anak dalam lingkungan sosial yang mereka buat sendiri. Dengan kata lain, untuk membatasi bahaya sosial, orang tua - orang tua dalam kategori ini membatasi secara ketat afiliasi sosial - afiliasi sosial atau keikutsertaan anak dalam lingkungan sosial di luar rumah. Secara sadar mereka mencoba membuat batas isolasi sosial - dalam membesarkan anak agar anak bisa tumbuh dalam tata nilai yang disepakati oleh orang tua.

Para orang tua dalam kategori ini tergolong orang-orang yang berpendidikan tinggi, tidak kekurangan secara finansial, mampu menggunakan teknologi informasi dan komunikasi yang canggih, sebagian besar sangat fasih berbahasa Inggris bahkan pernah tinggal di negara maju untuk sekolah atau bekerja. Mereka memutuskan melakukan 'isolasi sosial' dengan tujuan melindungi anak-anak mereka hingga secara fisik dan mental anakanak memasuki usia dimana mereka dapat mengambil keputusan untuk diri mereka sendiri dan melindungi diri sendiri.

"Isolasi sosial" itu dilakukan dengan membatasi "ruang gerak" anakanak baik secara fisik maupun secara sosial dalam bentuk :

a. Memilihkan teman bermain di lingkungan rumah.

b. Memilih sekolah, sebagian memilih sekolah rumah atau home schooling, dengan mendidik dan menangani materi dan metode pendidikan anak oleh orang tua. 
c. Sangat ketat dengan tata nilai dan atau agama.

d. Mempertahankan permainan manual.

e. Menutup saluran TV dan internet, tapi memilihkan film edukasi dalam bentuk off line.

f. Mengizinkan saluran internet secara terbatas setelah anak "cukup umur" atau melakukan counter framing dengan mendampingi langsung anak saat berselancar.

Untuk mengimbangi "isolasi sosial" yang dilakukan, agar anak-anak mereka bisa "go global" dan berkualitas, para orang tua ini banyak yang membiasakan anak-anak mereka berbahasa Inggris sedari kecil. Orang tua yang tidak bisa mengajari sendiri, mengkursuskan anak di kursus bahasa Inggris.

Tulang punggung pendidikan keluarga seperti ini pada umumnya adalah ibu rumah tangga. Sebagian ibu rumah tangga kategori ini memutuskan untuk berkonsentrasi membesarkan anak di rumah, memilih tidak bekerja atau melepaskan pekerjaan kantoran. Para perempuan ibu rumah tangga ini sebelumnya adalah perempuanperempuan sukses dalam pendidikan dan karir. Mereka memutuskan berbagi peran dengan suami dimana suami berkonsentrasi mencari uang dan istri mendidik anak. Sebagian lagi perempuan yang tetap bekerja memilih jenis pekerjaan yang memungkinkan mereka tetap dekat dengan anak, seperti menjadi pekerja paruh waktu. Bagi mereka, membesarkan anak adalah kewajiban terbesar dalam hidup. Zaman sekarang, sulit sekali menitipkan anak pada pihak lain. Bahkan pada sekolah sekalipun.

Dalam keseharian, keluargakeluarga kecil ini tetap membaur dan bergaul dengan tetangga ataupun lingkungan sosial lainnya. Para orang tua tidak membuat batas secara fisik dengan membatasi pertemuan atau sosialisasi dengan tetangga atau kelompok sosial lain. Para orang tua bahkan sangat aktif dalam berbagai kegiatan keagamaan. Namun demikian mereka membatasi pergaulan sosial anak-anak hanya dengan orang-orang atau keluarga yang mereka anggap memiliki tata nilai yang sama. Kondisi ini mungkin saja disadari oleh para tetangga atau lingkungan sosial lainnya. Untuk itu para orang tua ini mengaku siap dianggap berbeda.

Atas dasar tersebut maka masalah dalam penelitian ini dirumuskan menjadi : "Bagaimana konstruksi ibu tentang pola asuh atau pola didik terhadap anak dalam keluarga untuk menyiapkan anak memasuki usia dewasa?" Pola asuh atau pola didik terhadap anak dalam keluarga tentunya mencakup banyak hal, namun untuk penelitian ini, pola asuh atau pola didik dalam keluarga difokuskan pada aspek :

a. Bagaimana konstruksi orang tua (ibu) tentang pengembangan konsep diri anak? 
b. Bagaimana konstruksi orang tua (ibu) tentang isolasi sosial yang harus dilakukan terhadap anak dalam upaya untuk melindungi anak dari polusi sosial?

c. Bagaimana keyakinan orang tua (ibu) tentang kemampuan anak untuk beradaptasi dalam pergaulan sosial setelah anak menjadi lebih besar dan harus bergaul dalam masyarakat luas?

\section{TINJAUAN PUSTAKA}

Dalam kehidupannya, manusia melewati beberapa tahap perkembangan. Menurut George Herbert Mead, diri manusia berkembang secara bertahap melalui interaksi dengan anggota masyarakat lain. Tahapan tersebut terdiri dari :

\section{Tahap persiapan (Preparatory Stage)}

Tahap ini dialami sejak manusia dilahirkan, saat seorang anak mempersiapkan diri untuk mengenal dunia sosialnya. Pada tahap ini juga anak mulai melakukan kegiatan meniru meski tidak sempurna. Dalam tahap ini, individu sebagai calon anggota masyarakat dipersiapkan dengan dibekali nilai-nilai dan norma-norma yang menjadi pedoman bergaul dalam masyarakat oleh lingkungan yang terdekat, yaitu keluarga. Lingkungan yang memengaruhi termasuk individu yang berperan dalam tahapan ini relatif sangat terbatas, sehingga proses penerimaan nilai dan norma juga masih dalam tataran yang paling sederhana.

\section{Tahap Meniru (Play Stage)}

Tahap ini ditandai dengan semakin sempurnanya seorang anak menirukan peran-peran yang dilakukan oleh orang dewasa. Pada tahap ini mulai terbentuk kesadaran tentang nama diri dan siapa nama orang tuanya, kakaknya, dan sebagainya. Anak mulai menyadari tentang apa yang dilakukan oleh seorang ibu dan apa yang diharapkan seorang ibu dari dirinya. Dengan kata lain, kemampuan untuk menempatkan diri pada posisi orang lain juga mulai terbentuk pada tahap ini. Kesadaran bahwa dunia sosial manusia berisikan orang-orang yang jumlahnya banyak telah juga mulai terbentuk.

\section{Tahap Siap Bertindak (Game Stage)}

Peniruan yang dilakukan sudah mulai berkurang dan digantikan peran yang secara langsung dimainkan sendiri dengan penuh kesadaran. Kemampuannya menempatkan diri pada posisi orang lain pun meningkat, sehingga memungkinkan adanya kemampuan bermain secara bersamasama. Pada tahap ini individu mulai berhubungan dengan teman teman sebaya di luar rumah. Peraturanperaturan yang berlaku di luar keluarganya secara bertahap mulai dipahami. Bersamaan dengan itu, anak mulai menyadari bahwa ada norma tertentu yang berlaku di luar keluarganya.

\section{Tahap Penerimaan Norma Kolektif (Generalizing Stage)}


Pada tahap ini seseorang telah dianggap dewasa. Dia sudah dapat menempatkan dirinya pada posisi masyarakat secara luas. Dengan kata lain, dia dapat bertenggang rasa tidak hanya dengan orang-orang yang berinteraksi dengannya, tetapi juga dengan masyarakat secara luas. Manusia dewasa menyadari pentingnya peraturan, kemampuan bekerja sama, bahkan dengan orang lain yang tidak dikenalnya. Manusia dengan perkembangan diri pada tahap ini telah menjadi warga masyarakat dalam arti sepenuhnya. Dalam tahap ini, individu dinilai sudah mencapai tahap kematangan untuk siap terjun dalam kehidupan masyarakat.

Pada saat kita berinteraksi dengan orang lain tidak semua orang memberikan pengaruh yang sama pada kita. Pengaruh tidak akan kita rasakan dari orang yang tidak kita kenal dan sebaliknya kita lebih banyak dipengaruhi oleh orang-orang yang kita kenal, siapa yang kita hormati dan yang kita hargai pendapatnya. Mereka yang peduli dalam hidup kita adalah "significant others" kita dan mereka termasuk orang-orang yang kita cintai dalam keluarga, rekan kerja, dan temanteman dekat(Zhao, 2005).

Orang tua sebagai significant other pertama dalam kehidupan anak, membentuk konsep diri dan perkembangan diri anak. Konsep diri adalah pandangan dan sikap individu terhadap diri sendiri. Pandangan diri terkait dengan dimensi fisik, karakteristik individual, dan motivasi diri. Pandangan diri tidak hanya meliputi kekuatan-kekuatan individual, tetapi juga kelemahan bahkan juga kegagalan dirinya. Konsep diri merupakan inti dari kepribadian individu. Inti kepribadian berperan penting untuk menentukan dan mengarahkan perkembangan kepribadian serta perilaku individu. Konsep diri bisa diperoleh lewat informasi yang diberikan orang lain pada diri individu (Mulyana, 2003). Karenanya, konsep diri terkait dengan kemampuan menanggapi keadaan diri, kemampuan menerima pada keadaan, serta kemampuan bersosialisasi.

Penjelasan tentang proses sosial diterangkan oleh tokoh sosiologi pengetahuan Peter Berger dan Thomas Luckmann dalam teori Konstruksi Sosial atas Realitas (SCOR - Social Construction of Reality). Proses sosial itu sendiri terjadi melalui tindakan dan interaksi dimana individu atau sekelompok individu, menciptakan secara terus-menerus suatu realitas yang dimiliki dan dialami bersama secara subjektif (Berger \& Luckmann, 2012).

Setiap peristiwa merupakan realitas sosial objektif dan merupakan fakta yang benar-benar terjadi. Realitas sosial objektif ini diterima dan diinterpretasikan sebagai realitas sosial subjektif dalam diri individu yang menyaksikan peristiwa tersebut. Berger dan Luckmann berpandangan bahwa kenyataan itu dibangun secara sosial, dimana individu-individu dalam 
masyarakat telah membangun masyarakat, sehingga pengalaman individu tidak dapat terpisahkan dengan masyarakat. Manusia merupakan pencipta kenyataan sosial yang objektif, yang melalui 3 (tiga) momen dialektis secara simultan (Sobur, 2013)(Eriyanto, 2007), yaitu:

Pertama, eksternalisasi, yaitu usaha pencurahan atau ekspresi diri manusia ke dalam dunia, baik dalam kegiatan mental maupun fisik. Ini sudah menjadi sifat dasar manusia, ia akan selalu mencurahkan diri ke tempat dimana ia berada. Manusia tidak dapat kita mengerti sebagai ketertutupan yang terlepas dari dunia luarnya. Manusia berusaha menangkap dirinya, dimana ia berada dalam suatu dunia yang ia cerna.

Kedua, objektivasi, yaitu hasil yang telah dicapai, baik secara mental maupun fisik dari eksternalisasi manusia tersebut. Hasil itu menghasilkan realitas objektif yang bisa jadi akan menghadapi si penghasil itu sendiri sebagai suatu faktisitas yang berada diluar dan berlainan dari manusia yang menghasilkannya. Hasil dari eksternalisasi-kebudayaan itu misalnya, manusia menciptakan alat demi kemudahan hidupnya, atau kebudayaan non material dalam bentuk bahasa.

Baik alat maupun bahasa adalah bagian dari kegiatan eksternalisasi manusia ketika berhadapan dengan dunia. Keduanya adalah hasil dari kegiatan manusia. Setelah dihasilkan, benda maupun bahasa sebagai produk ekternalisasi tersebut menjadi realitas yang objektif. Bahkan ia dapat menghadapi manusia sebagai penghasil produk dari kebudayaan. Kebudayaan yang telah berstatus sebagai realitas objektif, ada di luar kesadaran manusia, ada "di sana" bagi setiap orang. Realitas objektif itu berbeda dengan realitas subjektif perorangan. Ia menjadi kenyataan empiris yang bisa dialami oleh setiap manusia.

Ketiga, internalisasi. Proses internalisasi lebih merupakan penyerapan kembali dunia objektif ke dalam kesadaran sedemikian rupa, sehingga kesubjektivan individu dipengaruhi oleh struktur dunia sosial. Berbagai macam unsur dari dunia yang telah terobjektifkan tersebut akan ditangkap sebagai gejala relitas diluar kesadarannya, sekaligus sebagai gejala internal bagi kesadaran. Melalui internalisasi, manusia menjadi hasil dari masyarakat.

Bagi Berger, realitas itu tidak dibentuk secara alamiah, tidak juga sesuatu yang diturunkan oleh Tuhan. Tetapi sebaliknya, ia dibentuk dan dikonstruksikan. Setiap orang bisa mempunyai konstruksi yang berbedabeda atas dasar suatu realitas. Setiap orang yang mempunyai pengalaman, preferensi, pendidikan tertentu dan lingkungan pergaulan atau sosial tertentu akan menafsirkan realitas sosial itu dengan 
konstruksinya masing-masing (Eriyanto, 2007).

Pada tahap eksternalisasi, sebuah tingkah laku masih disesuaikan dengan kemauan aktornya. Pada tahap objektivasi, sebuah tingkah laku sudah disesuaikan dengan tuntutan pranata, sekalipun bertentangan dengan keinginan pelakunya. Pada saat pranata itu disadari hanya sebagai buatan saja, terjadilah tahap internalisasi (Sobur, 2013). Kesadaran itu sendiri selalu intensional, ia selalu terarah kepada obyek(Berger \& Luckmann, 2012).

Terdapat dua cara pandang terhadap sosialisasi, yaitu cara pandang sosiologi dan psikologi. Secara mendasar sosialisasi adalah cara seseorang mempelajari norma dan kepercayaan dalam masyarakat. Sosialisasi adalah proses dimana orang belajar untuk menjadi anggota sebuah kelompok dalam masyarakat. Titik temunya dengan psikologi diterangkan oleh seorang psikolog yang banyak meneliti perkembangan anak, Jean Piaget (1896 - 1980). Menurut Piaget, perkembangan dari evolusi diri adalah negosiasi antara dunia yang eksis dalam anggapan diri seseorang dan dunia yang eksis dalam pengalaman sebuah masyarakat(Little, 2014).

Secara sadar maupun tidak sadar, orang tua melakukan serangkaian tindakan dan strategi untuk menyiapkan anak agar siap terjun dalam kehidupan bermasyarakat atau bersosialisasi dalam masyarakat. Untuk itulah orang tua mengawalinya dengan membangun kesadaran pada diri anak. Banyak cara dilakukan orang tua untuk membentuk diri anak, seperti menjembatani proses sosialisasi anak dengan berbagai hal yang ada di lingkungan sekitar anak, yang dimulai dari lingkungan keluarga inti serta lingkungan lain yang lebih besar. Dalam menjembatani proses sosialisasi anak terjadi proses intersubjektivitas atau proses berbagi makna antara orang tua dan anak, transfer nilai-nilai yang diyakini oleh orang tua, serta pembentukan perilaku anak agar sesuai dengan harapan orang tua.

\section{METODE PENELITIAN}

Penelitian ini termasuk ke dalam penelitian kualitatif dengan pendekatan fenomenologi. Penelitian dilakukan terhadap lima orang tua, yaitu ibu, baik ibu bekerja penuh waktu, ibu bekerja paruh waktu, maupun ibu rumah tangga, yang memiliki kesamaan strategi dalam membesarkan anak, yaitu dengan membatasi pergaulan anak di luar rumah atau di luar keluarga melalui strategi tertentu. Dalam penelitian ini strategi tersebut diberi istilah isolasi sosial.

Data diperoleh melalui pengamatan terhadap aktivitas seharihari lima orang informan dan keluarganya, serta wawancara. Karena kelima informan penelitian ini termasuk orang-orang yang sangat aktif di media sosial, maka sumber data elektronik yang memuat aktivitas informan di 
media sosial menjadi salah satu sumber data utama dalam penelitian ini.

Sebagai sebuah kajian fenomenologi, penelitian ini menggali pengalaman sehari-hari para informan tentang konsep isolasi sosial yang dilakukan oleh orang tua selama masa pembentukan karakter dan konsep diri anak, atau seperti yang disebut Berger dan Luckmann selama masa sosialisasi primer. Studi yang mendeskripsikan pemaknaan umum dari sejumlah individu terhadap berbagai pengalaman hidup mereka terkait dengan konsep atau fenomena ini digolongkan ke dalam studi fenomenologi (Creswell, 1998). Dengan kata lain, sebuah penelitian fenomenologis mencoba untuk menjawab pertanyaan "Bagaimana rasanya mengalami hal ini dan itu?" (Sobur, 2013).

Pada penelitian fenomenologi, seperti dikutip Creswell dari Moustakas (1994) peneliti kemudian mengumpulkan data dari individu yang telah mengalami fenomena tersebut. Dalam konteks penelitian ini, individuindividu tersebut adalah para ibu rumah tangga baik yang bekerja di luar rumah maupun tidak bekerja diluar rumah. Pengalaman para informan tentang konsep isolasi sosial yang mereka lakukan selama masa sosialisasi primer anak-anak mereka kemudian dideskripsikan oleh peneliti. Lebih lanjut peneliti mengembangkan deskripsi gabungan tentang esensi dari pengalaman tersebut bagi semua individu itu.
Analisis data dilakukan dengan mengikuti prosedur sistematis, bergerak dari satuan analisis yang sempit, misalnya tentang pembiasaan yang dilakukan orang tua (Ibu) dalam upaya mengenalkan makna sebuah fenomena atau perilaku pada anaknya, menuju satuan yang lebih luas berupa kesatuan makna, kemudian menuju deskripsi detail, yang merangkum dua unsur, yaitu "apa" yang telah dialami oleh individu, dan "bagaimana" mereka mengalaminya.

Atas dasar pertimbangan etik, identitas informan dijaga kerahasiaannya selama dan sesudah penelitian. Semua informan diberi nama lain sebagai sebutan pembeda untuk kepentingan penelitian.

\section{HASIL PENELITIAN DAN PEMBAHASAN}

Anak merupakan titipan yang Maha Kuasa untuk dijaga dan dibesarkan dengan tata nilai yang baik. Sayangnya, dunia luar rumah sangatlah heterogen dan tidak begitu ramah bagi anak. Sebut saja pergaulan dengan tata nilai yang tidak disepakati orang tua, ancaman paparan pornografi atau obat terlarang merupakan hal-hal yang perlu dijauhkan dari diri anak. Karenanya, anak perlu dilindungi, disiapkan secara fisik dan mental agar manakala anak harus ke luar dari rumah, ia telah siap menghadapi berbagai keadaan termasuk keadaan yang tidak ramah bahkan berbahaya. 
Begitulah keyakinan seluruh informan penelitian ini. Sebagian informan saling mengenal satu sama lain, sebagian lagi tidak. Meski tidak semuanya saling mengenal, semua informan memiliki kesamaan dalam cara pandang terhadap kehadiran anak dalam keluarga. Kesamaan inilah yang membentuk cara pandang yang sama pada aspek tertentu dan hingga derajat tertentu terhadap konsep membesarkan anak.

Keyakinan tentang proteksi yang harus dilakukan terhadap anak memunculkan strategi pendidikan anak yang khas pada diri informan. Tiga orang informan memilih membina semua anak mereka dalam konsep sekolah rumah atau lebih populer disebut home schooling, sementara dua lainnya memilih menyekolahkan anakanak mereka di sekolah umum, namun dengan pendampingan intensif dimana orang tua terlibat sangat aktif dalam proses pendidikan anak di sekolah. Dapat dikatakan seluruh informan adalah aktivis pemerhati pendidikan anak. Dua informan aktif menyebarluaskan gagasan tentang pendidikan dan tumbuh kembang anak di media sosial hingga. Keduanya memiliki ribuan pengikut (follower) di media sosial. Sedangkan tiga informan lain juga aktif dalam komunitas pemerhati pendidikan anak, namun dalam bentuk yang berbeda. Ketiganya rutin menyelenggarakan berbagai kegiatan seputar tumbuh kembang anak baik untuk orang tua maupun anak, yang terbuka dan gratis diikuti oleh siapapun. Strategi ini mereka pilih dalam upaya mereka untuk memberikan lingkungan sosial yang baik bagi anakanak mereka. Bagi seluruh responden, karena mereka tidak bisa mengubah seluruh dunia, maka mereka menyediakan batas lingkungan sosial mana yang boleh dimasuki oleh anakanak mereka. Untuk itu mereka juga harus membuat lingkungan sosial sendiri yang cukup aman dan ramah bagi anak-anak mereka. Mereka membangun strategi untuk membangun lingkungan yang aman dan ramah bagi anak.

\section{a. Masa Sosialisasi Primer : \\ Membangun Tata Nilai Keluarga Melalui Pembiasaan}

Seperti dikatakan Berger dan Luckmann (2012) semua kegiatan manusia bisa mengalami proses pembiasaan (habituasi). Tiap tindakan yang sering diulangi pada akhirnya akan menjadi suatu pola yang kemudian bisa direproduksi dengan upaya sekecil mungkin. Melalui pembiasaan, tindakan yang sama selanjutnya dapat dilakukan kembali di masa mendatang dengan cara yang sama dan dengan upaya yang sama ekonomisnya. Ini berlaku bagi aktivitas sosial maupun non-sosial. Sudah tentu tindakan-tindakan yang sudah menjadi kebiasaan itu mempertahankan sifatnya yang bermakna bagi individu. Pembiasaan memberikan arah bagi kegiatan manusia, serta menghemat energi pada 
saat seseorang harus mengambil keputusan pada kesempatan tertentu.

Demikian pula pembiasaan yang dilakukan oleh para ibu terhadap anaknya. Para orang tua, dalam konteks penelitian ini adalah para ibu sebagai significant others yang pertama kali dikenal oleh seorang anak, melakukan pembiasaan-pembiasaan tertentu dalam mendidik anak atau anak-anaknya. Pembiasaan ini dilakukan untuk membentuk pola perilaku anak.

Pola pembiasaan ibu dimulai dengan menjalin kedekatan secara fisik dan psikologis dengan anaknya. Para informan memulai kedekatan saat mereka mengandung anak-anak mereka dengan melakukan hal-hal yang mereka yakini dapat membentuk kedekatan baik secara fisik maupun psikologis dengan anak mereka. Informan muslim membiasakan diri mengaji untuk diperdengarkan kepada janin dalam kandungan, sedangkan informan non muslim memilih untuk memperdengarkan lagu-lagu atau musik klasik kepada calon bayi mereka sejak dalam kandungan. Seluruh informan meyakini bahwa kedekatan dengan anak dapat dibangun sejak dalam kandungan, seperti banyak diceritakan oleh para dokter maupun berbagai hasil penelitian ilmiah. Seluruh informan juga menekankan bahwa orang tua, baik ayah maupun ibu, harus menjadi orang yang paling dekat dengan anak, atau dapat diterjemahkan menjadi significant others terdekat yang paling berpengaruh bagi anak. Lebih dari itu, karena ibu yang mengandung, maka seorang ibu harus menjadi orang pertama dan utama bagi seorang anak.

Pembiasaan diawali dengan membiasakan janin dalam kandungan mendengarkan doa, musik klasik, serta ucapan atau kata-kata yang baik dari ibu yang mengandungnya. Setelah lahir, kebiasaan yang diyakini perlu dibentuk ini dilanjutkan oleh kedua orang tua. Seluruh tindakan pembiasaan dilakukan berdasarkan nilai-nilai yang diyakini oleh kedua orang tua. Dalam seluruh kegiatan pembiasaan ini, ibu mengambil peran sangat penting, menjadi yang pertama dan utama. Seluruh informan menyakini bahwa ibu adalah benteng paling penting yang dapat melindungi anak dari bahaya dunia luar, pembangun karakter anak yang paling penting dan utama. Karena perannya yang tak tergantikan, maka seorang ibu harus merelakan seluruh hidupnya, waktu, tenaga, pikiran, energi beserta segala hal yang ada dalam dirinya untuk dicurahkan bagi sang anak. Keyakinan ini muncul karena nilai-nilai yang dianut oleh informan.

$$
\text { Dalam menjalani kehidupan }
$$
sehari-hari terbentuklah berbagai pembiasaan berbagi peran antara ayah dan ibu. Seluruh informan mengaku tidak memiliki masalah dalam pembagian peran ayah dan ibu dalam keluarga. Tidak pernah ada isu ketimpangan gender atau upaya kesetaraan pembagian peran ayah atau ibu dalam keluarga mereka, baik yang pernah diucapkan atau yang tidak 
pernah diucapkan. Dalam keluarga tiga informan, ayah berperan sebagai pencari nafkah utama keluarga, sedangkan ibu memutuskan untuk mengambil peran pendidik utama bagi anak. Ketiga ibu ini selalu mendampingi segala aktivitas anak hingga anak menyelesaikan pendidikan sekolah dasar mereka.

Informan yang menganut konsep home schooling menjadi guru utama bagi anak-anak mereka. Latar belakang pendidikan yang tinggi pada diri informan membuat mereka sanggup mengajari berbagai mata pelajaran sekolah hingga tingkat SD, seperti mengajar sains atau Ilmu Pengetahuan Alam, Bahasa Indonesia, Ilmu Pengetahuan Sosial, Matematika, Agama, serta Bahasa Inggris. Sedangkan informan yang menyekolahkan anak ke sekolah dasar umum, senantiasa memantau perkembangan anaknya setiap hari secara ketat, misalnya dengan mengantar jemput anaknya dan selalu membawa serta anaknya ke berbagai kegiatan sang ibu.

Dari segi makna-makna yang diberikan oleh manusia kepada kegiatannya, pembiasaan menyebabkan tidak perlunya lagi setiap situasi didefinisikan kembali, langkah demi langkah. Pembiasaan juga menyepakati makna terhadap sebuah realitas, perilaku, tindakan atau peristiwa, sehingga terjadilah apa yang disebut intersubjektivitas - penyampaian makna-makna dan nilai-nilai tentang realitas tertentu. Penyampaian makna tentang peristiwa tertentu dari seorang ibu kepada anak atau anak-anaknya, diyakini akan membuat anak memiliki makna yang sama terhadap realitas tertentu.

Proses pembiasaan ini diawali dari keyakinan pada diri orang tua, dalam hal ini seorang ibu. Keputusan untuk membuat batas pergaulan atau interaksi sosial dibuat karena keyakinan bahwa terdapat bahaya dalam dunia diluar sana, sehingga seseorang perlu selalu memilih lingkungan sosial yang diyakini aman dan bermanfaat. Keyakinan ini juga membuat seorang ibu perlu mengambil keputusan memilih lingkungan sosial yang tepat bagi sang anak. Proses-proses pembiasaan ini mendahului setiap pelembagaan, malahan dapat dibuat sedemikian rupa sehingga bisa berlaku bagi seorang individu yang hidup menyendiri, terkucil dari interaksi sosial.

Tabel berikut ini menjelaskan strategi pendidikan anak yang dipilih oleh masing-masing informan. 
Tabel 1. Strategi Mendidik Anak

\begin{tabular}{|c|c|c|c|c|}
\hline & $\begin{array}{c}\text { Konsep belajar } \\
\text { anak }\end{array}$ & Ruang Sosial Anak & $\begin{array}{c}\text { TIK yang diberikan } \\
\text { pada Anak }\end{array}$ & $\begin{array}{l}\text { Sarana TIK di } \\
\text { rumah }\end{array}$ \\
\hline Kiki & $\begin{array}{l}\text { Home schooling } \\
\text { dengan menangani } \\
\text { sendiri (berbagi tugas } \\
\text { dengan suami) } \\
\text { seluruh pelajaran } \\
\text { anak hingga usia SD. } \\
\text { Setelah SMP } \\
\text { disekolahkan di } \\
\text { pesantren }\end{array}$ & $\begin{array}{l}\text { Cenderung } \\
\text { mengundang teman } \\
\text { anak ke rumah dari } \\
\text { pada membiarkan } \\
\text { anak bermain ke } \\
\text { rumah teman. } \\
\text { Menyekolahkan anak } \\
\text { ke TPA untuk } \\
\text { mengaji dan } \\
\text { pergaulan sosial anak. }\end{array}$ & \multirow{5}{*}{$\begin{array}{l}\text { Telepon selular } \\
\text { hanya untuk telpon } \\
\text { dan SMS sebagai alat } \\
\text { komunikasi dgn } \\
\text { orang tua dan orang- } \\
2 \text { terdekat spt guru - } \\
\text { diberikan pada usia } \\
\text { anak } 10 \text { tahunan. } \\
\text { Sulis, Kasih : laptop } \\
\text { (off line) pribadi } \\
\text { untuk anak setelah } \\
\text { usia } 10 \text { tahunan } \\
\text { Wati, Kiky : laptop } \\
\text { pribadi untuk anak } \\
\text { setelah anak SMP } \\
\text { untuk kebutuhan } \\
\text { sekolah di pesantren }\end{array}$} & $\begin{array}{l}\text { TV, laptop, } \\
\text { tablet, semua } \\
\text { off line untuk } \\
\text { sarana edukasi } \\
\text { telepon selular } \\
\text { sederhana } \\
\text { untuk anak } \\
\text { SMP }\end{array}$ \\
\hline Sulis & $\begin{array}{l}\text { Home schooling } \\
\text { dengan menangani } \\
\text { sendiri seluruh } \\
\text { pelajaran anak } \\
\text { (berbagi tugas } \\
\text { dengan suami). }\end{array}$ & $\begin{array}{l}\text { Mengajak anak } \\
\text { berkumpul dengan } \\
\text { sesama peserta home } \\
\text { schooling anak di } \\
\text { waktu-2 tertentu. } \\
\text { Mengkursuskan anak } \\
\text { pada bidang yang } \\
\text { diminati anak : les } \\
\text { musik, tari. }\end{array}$ & & $\begin{array}{l}\text { Sulis dan Melly } \\
\text { : TV yang } \\
\text { terhubung } \\
\text { dengan antena, } \\
\text { namun selalu } \\
\text { ditonton } \\
\text { bersama } \\
\text { sehingga anak } \\
\text { selalu }\end{array}$ \\
\hline Melly & $\begin{array}{l}\text { Sekolah di sekolah } \\
\text { negeri }\end{array}$ & $\begin{array}{l}\text { Menyekolahkan anak } \\
\text { di sekolah umum } \\
\text { negeri, namun dengan } \\
\text { memantaunya secara } \\
\text { teliti. }\end{array}$ & & $\begin{array}{l}\text { didampingi } \\
\text { Laptop off line } \\
\text { Telepon selular } \\
\text { sederhana }\end{array}$ \\
\hline Wati & $\begin{array}{l}\text { Sekolah di tempat } \\
\text { terpilih yang dikelola } \\
\text { oleh teman/relasi } \\
\text { dekat yang dapat } \\
\text { dipercaya. }\end{array}$ & $\begin{array}{l}\text { Menyekolahkan anak } \\
\text { di sekolah umum } \\
\text { swasta yang dikelola } \\
\text { teman, dengan } \\
\text { memantaunya secara } \\
\text { teliti. }\end{array}$ & & $\begin{array}{l}\text { Laptop, tablet, } \\
\text { semua off line } \\
\text { untuk sarana } \\
\text { edukasi telepon } \\
\text { selular } \\
\text { sederhana } \\
\text { untuk anak } \\
\text { SMP }\end{array}$ \\
\hline Kasih & $\begin{array}{l}\text { Home schooling } \\
\text { dengan menangani } \\
\text { sendiri seluruh }\end{array}$ & $\begin{array}{l}\text { Mengajak anak } \\
\text { berkumpul dengan } \\
\text { sesama peserta home }\end{array}$ & & $\begin{array}{l}\text { TV yang } \\
\text { terhubung } \\
\text { dengan antena, }\end{array}$ \\
\hline
\end{tabular}




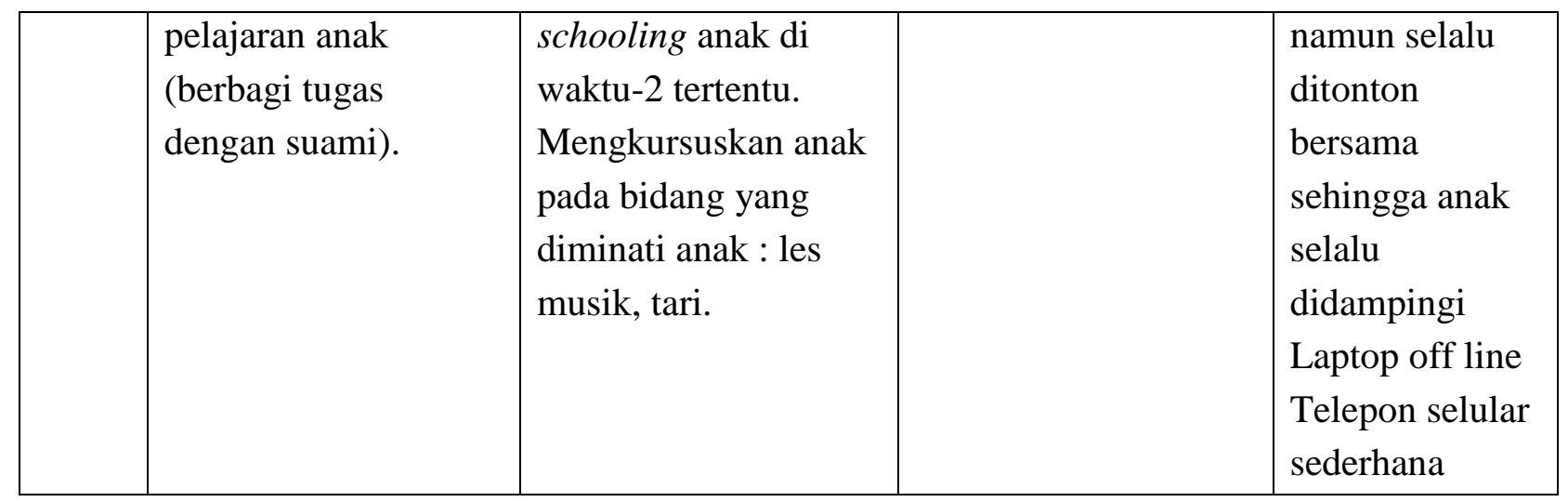

Saat melakukan aktivitas bersama sehari-hari anak akan melihat pembagian peran ayah dan ibu dalam keluarga, mencerna nilai-nilai yang dianut oleh ayah ibu, serta berperilaku dan bertindak sesuai arahan orang tua. Pada saat ini akan juga melihat tipifikasi, sebuah istilah yang merujuk kepada jenis-jenis tindakan yang dilakukan berulang-ulang atau sudah menjadi pembiasaan. Pada saat inilah proses peniruan itu terjadi, baik peniruan dalam tahap mencerna makna maupun motif dan perilaku.

Seluruh informan menyadari bahwa tahap mencerna makna dan peniruan ini merupakan tahap penting dalam proses transfer nilai-nilai yang dianut oleh orang tua hingga terinternalisasi pada diri anak. Pada tahap ini orang tua tidak boleh lengah untuk menanamkan nilai-nilai dan perilaku yang mereka yakini benar. Para orang tua melakukannya melalui dialog, bimbingan, contoh perilaku, dan penanam orientasi nilai-nilai kehidupan.
Seluruh informan mengakui, tidak mudah menanamkan nilai-nilai yang diyakini oleh orang tua pada saat lingkungan sosial menyatakan hal berbeda. Sebagai contoh, tidak mudah menanamkan untuk tidak menggunakan televisi pada saat seluruh lingkungan tetangga memiliki televisi di rumah masing-masing. Orang tua tentu saja sudah memberikan alasan kepada anakanak agar menerima, hingga terinternalisasi dengan baik dalam dirinya tentang keputusan untuk tidak menggunakan televisi. Demikian pula pada contoh untuk selalu menggunakan barang sesuai kebutuhan, termasuk memilih pakaian yang belum tentu sesuai dengan mode yang tengah berkembang, menggunakan kendaraan umum dari pada membeli kendaraan pribadi, menggunakan bahan-bahan ramah lingkungan, menghindari jajanan makanan instan, dan keputusankeputusan lain yang berbeda dengan arus utama lingkungan sosial.

Agar anak tetap berada dalam koridor yang ditetapkan orang tua serta 
meyakini bahwa apa yang ditanamkan oleh orang tua terhadap mereka adalah hal yang baik dan benar, para ibu kemudian memilihkan teman-teman serta lingkungan sosial yang memiliki tata nilai yang sama dengan nilai-nilai yang dianut oleh keluarga mereka. Proses ini penting untuk meyakinkan, sebagai bagian dari tahap eksternalisasi dan objektivasi bahwa yang keluarga merka lakukan bukanlah hal aneh karena berbeda dari orang kebanyakan. Karena anak tidak boleh sembarangan bergaul, maka orang tua perlu mengenalkan anak pada dunia luar yang telah dibentuk oleh orang-orang "sejenis" yang memiliki tata nilai sama. Orang-orang "sejenis" ini merupakan bukti bahwa keputusan dan tindakan yang dilakukan oleh orang tua bukan hal aneh, melainkan perlu dilakukan untuk melindungi anak.

Saat-saat penanaman nilai kepada anak merupakan saat-saat yang menguji konsistensi orang tua, menguras tenaga, waktu, dan pikiran. Momen ini juga menjadi momen ujian bagi para orang tua terutama ibu. Untuk itulah para informan mengakui bahwa mereka juga perlu berbagi perasaan dan keyakinan dengan sesama ibu yang menganut nilai-nilai yang sama. Kebutuhan pada tahap eksternalisasi dan objektivasi ini juga muncul pada diri para informan, bukan hanya karena alasan untuk menunjukkan bukti pada anak-anak mereka, namun juga sebagai tempat berbagi dengan sesama bagi diri para informan.

Para informan secara aktif berafiliasi kepada lembaga sosial yang menganut tata nilai sama dengan dirinya, atau membentuk lembaga sosial sendiri. Lembaga sosial tersebut tidak selalu formal, bergerak dalam bidang yang mereka minati seperti kelompok belajar agama, kelompok bermain anak, peer group discussion baik bagi anak maupun orang tua, kelompok hobi dan minat seperti parenting group, yoga, dan lain-lain. Tiga orang informan memutuskan untuk membentuk komunitas home schooling sendiri (masing-masing informan memiliki kelompok home schooling terpisah).

Tabel berikut ini menjelaskan konsep gaya hidup yang dipilih oleh para informan : 
Tabel 2. Gaya Hidup Keluarga dan Penanaman Tata Nilai Pada Anak

\begin{tabular}{|c|c|c|c|}
\hline & Strategi Gaya Hidup & $\begin{array}{c}\text { Pandangan tentang } \\
\text { "dunia di luar rumah" } \\
\text { bagi anak }\end{array}$ & $\begin{array}{l}\text { Nilai Utama dalam } \\
\text { Membesarkan Anak }\end{array}$ \\
\hline Kiki & $\begin{array}{l}\text { Hanya memiliki } \\
\text { barang/aset yang } \\
\text { dibutuhkan. } \\
\text { Namun tetap berusaha } \\
\text { memiliki tabungan dalam } \\
\text { bentuk uang dan } \\
\text { tanah/bangunan }\end{array}$ & $\begin{array}{l}\text { Nilai agama, budaya, dan } \\
\text { sosial telah banyak } \\
\text { merosot. Berbahaya bagi } \\
\text { tumbuh kembang anak. } \\
\text { Karenanya, anak harus } \\
\text { dilindungi }\end{array}$ & Nilai-nilai agama \\
\hline Sulis & $\begin{array}{l}\text { Hanya memiliki } \\
\text { barang/aset yang } \\
\text { dibutuhkan. } \\
\text { Berusaha memiliki } \\
\text { tabungan untuk kondisi } \\
\text { darurat. } \\
\text { Saat memiliki uang lebih } \\
\text { dialokasikan untuk } \\
\text { pengembangan rumah } \\
\text { belajar gratis bagi } \\
\text { masyarakat }\end{array}$ & $\begin{array}{l}\text { Dunia luar rumah sangat } \\
\text { heterogen. Anak harus } \\
\text { disiapkan untuk siap } \\
\text { menghadapi dunia yang } \\
\text { heterogen, agar anak bisa } \\
\text { memilih dan mengambil } \\
\text { keputusan yang tepat bagi } \\
\text { dirinya dan hidupnya. } \\
\text { Untuk itu orang tua harus } \\
\text { menyiapkan lingkungan } \\
\text { sosial yang tepat bagi anak. }\end{array}$ & $\begin{array}{l}\text { Nilai sosial, agar anak } \\
\text { mau mengabdikan } \\
\text { dirinya bagi masyarakat. } \\
\text { Membangun anak yang } \\
\text { berkarakter kokoh, } \\
\text { mampu mengambil } \\
\text { keputusan yang tepat dan } \\
\text { tidak mudah terpengaruh } \\
\text { lingkungan. }\end{array}$ \\
\hline Melly & $\begin{array}{l}\text { Hanya memiliki } \\
\text { barang/aset yang } \\
\text { dibutuhkan. } \\
\text { Berusaha memiliki } \\
\text { tabungan untuk kondisi } \\
\text { darurat. }\end{array}$ & $\begin{array}{l}\text { Dunia luar sangat } \\
\text { heterogen. Anak harus } \\
\text { diberi bekal mental yang } \\
\text { kuat. Untuk itu sebelum } \\
\text { anak siap, orang tua } \\
\text { membangun lingkungan } \\
\text { sosial yang sehat bagi } \\
\text { anak, hingga anak siap } \\
\text { memasuki dunia luar. }\end{array}$ & $\begin{array}{l}\text { Nilai sosial, agar anak } \\
\text { mau mengabdikan } \\
\text { dirinya bagi masyarakat. }\end{array}$ \\
\hline Wati & $\begin{array}{l}\text { Hanya memiliki } \\
\text { barang/aset yang } \\
\text { dibutuhkan. } \\
\text { Namun tetap berusaha } \\
\text { memiliki tabungan dalam } \\
\text { bentuk uang dan } \\
\text { tanah/bangunan }\end{array}$ & $\begin{array}{l}\text { Dunia luar sangat } \\
\text { berbahaya. Anak harus } \\
\text { disiapkan oleh orang tua } \\
\text { sebelum mengenal dunia } \\
\text { luar. Orang tua melindungi } \\
\text { dan mendampingi anak, } \\
\text { hingga anak memasuki usia }\end{array}$ & Nilai2 agama \\
\hline
\end{tabular}




\begin{tabular}{|l|l|l|l|}
\hline & & siap memasuki dunia luar. & \\
\hline Kasih & $\begin{array}{l}\text { Memiliki barang/aset } \\
\text { sesuai dibutuhkan. } \\
\text { Memiliki tabungan masa } \\
\text { depan dalam bentuk } \\
\text { asuransi dan tabungan } \\
\text { konvensional. }\end{array}$ & $\begin{array}{l}\text { Dunia luar sangat } \\
\text { heterogen. Orang tua harus } \\
\text { menemani anak hingga } \\
\text { secara fisik dan mental } \\
\text { anak siap menghadapi } \\
\text { dunia luar, secara bertahap. }\end{array}$ & $\begin{array}{l}\text { Anak hadibadi yang } \\
\text { ramah dan tangguh } \\
\text { menghadapi ujian hidup. }\end{array}$ \\
& & \\
\hline
\end{tabular}

\section{b. Penguatan Pada Masa Sosialisasi}

\section{Primer : Mengenalkan Konsep}

Perbedaan dan Menanamkan

\section{Keyakinan Pada Anak}

Pada saat anak memasuki usia sekolah atau sekitar empat tahun, anak akan mulai mengenal lingkungan sosial yang lebih luas selain keluarga intinya atau melewati tahap sosialisasi primer. Saat ini anak mulai mengenal adanya tetangga dan teman bermain dari lingkungan tetangga. Pada umumnya anak usia ini mulai masuk ke PAUD (Pendidikan Anak Usia Dini) atau Taman Pendidikan Al Qur'an (TPA) yang sudah banyak didirikan di hampir setiap pemukiman penduduk di masyarakat mayoritas muslim. Pada masa seperti ini, tantangan berikutnya yang harus dihadapi oleh para ibu adalah menjelaskan kepada anak tentang hal-hal yang boleh dan tidak boleh diterima anak dari orang di luar rumah. Pada tahap ini anak akan lebih merasakan tentang berbagai perbedaan tata nilai yang ia anut dibandingkan dengan teman-teman bermainnya. Sebagai contoh, anak-anak lain dapat dengan bebas jajan di warung sedangkan anak informan tidak diizinkan jajan di warung karena ibu telah memasak dan menyediakan makanan di rumah. Contoh lain adalah pengertian yang harus diberikan orang tua tentang mengapa keluarga mereka membatasi akses terhadap televisi, telepon selular, atau koneksi internet.

Informan mengakui tahap ini menjadi tahap tersulit yang harus dilakukan. Menanamkan nilai tentang alasan sebuah keputusan dan konsekuensi yang harus diterima dari sebuah keputusan, yang mungkin berbeda dari keputusan orang kebanyakan. Itu sebabnya orang tua khususnya ibu harus sangat selektif memilihkan teman pergaulan bagi anak. Kalaupun anak harus bertemu dengan anak-anak lain dengan pola asuh dan tata nilai berbeda, maka anak hanya diizinkan bertemu sebentar-sebentar. Agar anak mengerti cara bersosialisasi dengan teman seusia, maka anak hanya boleh berteman dekat dengan anak-anak lain yang memiliki tata nilai yang sama. Selama proses proteksi ini berlangsung, orang tua khususnya ibu harus mampu menjadi significant other yang pertama 
dan utama dalam kehidupan anak. Sumber pengaruh utama kehidupan anak adalah ibu, bukan nenek, pembantu, atau acara televisi. Untuk itu ibu harus dapat memberikan berbagai informasi yang diperlukan anak hingga cadangan pengetahuan anak memadai untuk mencerna atau memaknai hal-hal yang harus ia hadapi saat ini dan dimasa yang akan datang.

Proses proteksi ini harus berlangsung terus hingga orang tua, khususnya ibu yakin bahwa nilai-nilai penting telah tertanam kuat atau terinternalisasi pada diri anak sehingga anak cukup kokoh menghadapi perbedaan dan tidak terpengaruh oleh perbedaan.

Lalu kapan anak dirasakan atau dianggap telah mencapai tahap cukup untuk keluar dari lingkungan proteksi yang diberikan oleh orang tua? Seperti disebutkan Berger dan Luckmann (2012), setelah melewati tahap sosialisasi primer, seseorang akan memasuki tahap sosialisasi sekunder dalam kehidupannya. Sosialisasi sekunder adalah internalisasi sejumlah "sub-dunia" kelembagaan atau berlandaskan lembaga. Proses formal sosialisasi sekunder selalu mengandalkan proses sosialisasi primer yang mendahuluinya. Dengan demikian, proses untuk bersosialisasi dengan dunia luar selain dunia yang diproteksi oleh orang tua baru dapat dilakukan jika seorang anak telah dapat mengambil keputusan yang tepat untuk hidupnya sesuai dengan nilai-nilai yang dianut oleh orang tua.

Tidak ada jawaban pasti tentang pada saat apa, usia berapa, momentum apa, atau atas dasar faktor apa seorang anak dapat dilepas tanpa proteksi orang tua. Pada umumnya orang tua, dalam hal ini ibu, melepas proteksi secara bertahap, misalnya dengan mulai mengizinkan anak bermain internet tanpa pengawasan langsung orang tua memasuki usia SMP, namun sesungguhnya secara diam-diam orang tua masih tetap mengawasi di luar pengetahuan anak. Seluruh informan menyatakan bahwa paling lambat pada usia lulus SMA, anak-anak harus mandiri secara fisik maupun mental karena mungkin harus tinggal berjauhan dari orang tua untuk kepentingan kuliah. Mereka meyakini bahwa pada usia itu anak-anak akan telah siap untuk menghadapi dunia luar yang sangat heterogen dan mungkin berbahaya bagi diri.

\section{c. Transisi Sosialisasi Primer ke}

\section{Sosialisasi Sekunder : Menyiapkan}

Kemampuan Anak untuk

\section{Bersosialisasi di Tengah}

\section{Masyarakat}

Orang tua tidak mungkin memproteksi anak terus menerus karena pada suatu waktu anak akan harus terlibat dengan dunia di luar proteksi orang tua. Pekerjaan rumah besar yang harus dihadapi orang tua adalah menyiapkan kemampuan anak untuk bersosialisasi di tengah masyarakat atau 
menyiapkan masa transisi sosialisasi sekunder.

Semua informan mengatakan bahwa mereka menyiapkan masa transisi sosialisasi secara bertahap. Jika anak lolos pada tingkat kesulitan tahap pertama, maka anak akan dibawa untuk memasuki tingkat kesulitan tahap kedua. Sebagai contoh, jika anak dapat berteman dengan baik bersama temanteman yang dipilihkan orang tua, maka kemudian anak boleh memilih temannya sendiri. Jika anak telah dapat mematuhi aturan orang tua tanpa harus diawasi, maka anak akan diberi kepercayaan lebih. Jika anak telah dapat menggunakan telepon selular secara bijaksana, anak akan diizinkan membawa telepon selular dalam aktivitasnya sehari-hari.

Tantangan berikutnya yang harus dihadapi orang tua adalah menyiapkan anak bahwa orang di luar sana belum tentu memiliki tata nilai yang sama. Anak harus dapat menyikapi perbedaan dengan baik. Pada tahap ini seluruh informan mengatakan bahwa proses ini menjadi proses pembelajaran tidak saja bagi anak, tapi juga bagi orang tua, dalam konteks penelitian ini bagi para ibu.

Para informan adalah tokohtokoh anutan bagi komunitasnya masing-masing. Seluruh informan membekali diri mereka dengan pengetahuan agama maupun pengetahuan tentang tumbuh kembang anak (psikologi perkembangan) sebagai bekal untuk mendidik anak-anak mereka sendiri maupun ikut memberikan pengajaran kepada komunitas yang mereka bina. Pengetahuan ini menjadi bekal untuk keyakinan mereka tentang keputusan yang harus mereka ambil dalam mendidik anak. Orang tua juga harus memberi bekal tentang apa yang harus dilakukan jika orang lain menganggap keluarga mereka berbeda atau bahkan aneh.

Sebagai seorang ibu, pada intinya upaya yang mereka lakukan adalah mentransfer seluruh pengetahuan dan makna tentang kehidupan kepada anak-anak, agar anak-anak memiliki makna intersubjektif yang sama dengan orang tua mereka. Untuk itu orang tua perlu memeriksa jalinan komunikasi keluarga setiap waktu untuk meyakinkan bahwa nilai-nilai utama keluarga selalu menjadi referensi utama bagi setiap anggota keluarga dalam bersosialisasi dengan dunia sosial di luar keluarga.

Seluruh informan mengawali strategi pendidikan anak melalui pembiasaan yang terencana dan konsisten pada anak sejak anak dalam kandungan hingga masa sosialisasi primer. Pembiasaan ini merupakan bagian dari upaya menanamkan nilainilai yang diyakini orang tua kepada anak. Pada tahap ini orang tua berperan sebagai significant others yang pertama dan utama dengan menerjemahkan proses ekternalisasi berbagai tindakan serta perilaku kepada anak, sehingga anak meniru tindakan dan perilaku 
orang tua. Selanjutnya, dalam proses pembiasaan orang tua memberikan contoh pengambilan keputusan dalam berbagai kesempatan secara konsisten.

Pada tahap ini terjadi proses objektivasi, dimana orang tua masih menerjemahkan melalui penjelasan berbagai fenomena kepada anak. Seperti dinyatakan Berger dan Luckmann, objektivasi adalah hasil yang telah dicapai, baik secara mental maupun fisik dari eksternalisasi manusia tersebut. Hasil dari eksternalisasikebudayaan itu misalnya, manusia menciptakan alat demi kemudahan hidupnya, atau kebudayaan non material dalam bentuk bahasa. Fase ini terjadi melalui upaya orang tua untuk menyampaikan legitimasi berbagai keputusan yang harus mereka ambil, terhadap anak mereka.

Orang tua menjelaskan kepada anakberbagai alasan mengapa mereka mengambil keputusan tertentu yang mungkin saja berbeda dari keputusan orang tua yang lain. Fase ini ditandai dengan dialog antara orang tua dan anak. Pada fase ini orang tua juga memberikan anak berbagai fasilitas sebagai konsekuensi dari keputusan mereka, serta menjadi bagian dari strategi orang tua untuk mencapai tujuan atau cita-cita orang tua. Sebagai contoh, ketika orang tua memutuskan melarang anak jajan makanan instan di warung, maka mereka memberikan fasilitas pengganti dengan memasak aneka ragam makanan kudapan sehat di rumah, meski hal itu lebih menghabiskan biaya dan lebih melelahkan dibandingkan dengan. in

Orang tua juga secara aktif dan konsisten menunjukkan bahwa keputusan orang tua meski berbeda dengan orang kebanyakan namun normal dan bertujuan baik. Untuk itu orang tua juga perlu menunjukkan bahwa tidak hanya keluarga mereka yang mengambil keputusan berbeda dengan orang kebanyakan, keluarga lain juga melakukan hal serupa, meski jumlahnya lebih sedikit dari orang kebanyakan. Semua tindakan dan keputusan ini mendatangkan konsekuensi dimana orang tua mungkin harus lebih aktif atau "cerewet" memberikan penjelasan kepada anak serta konsisten dengan semua keputusan mereka.

Setelah melewati perjuangan panjang melalui aneka contoh atau pembiasaan, tipifikasi, serta penjelasan tentang alasan pengambilan keputusan, orang tua berharap agar nilai-nilai yang mereka tanamkan dapat terinternalisasi pada diri anak. Pada tahap ini, anak telah memperoleh keyakinan serta mulai dapat mengambil keputusan yang sesuai dengan nilai-nilai orang tua. Anak tidak lagi goyah ketika menghadapi perbedaan dari keadaan di luar keluarga mereka, atau perbedaan dengan kebiasaan orang lain selain keluarga. Tahap ini juga merupakan tahap transisi dari sosialisasi primer ke sosialisasi sekunder. Karena anak telah mampu mengambil keputusan yang sesuai dengan nilai-nilai yang ditanamkan 
orang tua, maka orang tua mulai melepaskan anak dan mengambil keputusan sendiri.

\section{KESIMPULAN}

Berdasarkan penelusuran data dan analisis, maka dapat dalam penelitian ini dapat disimpulkan beberapa hal, yaitu :

1) Konstruksi orang tua (ibu) tentang pengembangan konsep diri dan karakter anak.

Anak adalah titipan yang Maha Kuasa yang lahir dalam keadaan bersih dan harus diisi dengan baik. Orang tua adalah pihak yang paling banyak berperan alam mengisi atau membentuk konsep diri dan karakter anak. Dalam proses pengembangan konsep diri dan karakter anak, orang tua dalam hal ini ibu harus menjadi sumber rujukan (significant other)pertama dan utama bagi anak. Untuk mencapai hal itu, ibu harus membekali diri dengan pengetahuan yang memadai tentang pendidikan anak serta aneka pengetahuan yang diperlukan oleh anak pada masa sosialisasi primer anak. Kecukupan pengetahuan ibu akan memunculkan keyakinan pada diri ibu untuk memberi bekal yang kuat bagi anak saat harus melewati masa sosialisasi sekunder, dimana anak harus bergaul ke luar dari dunia sosial yang diproteksi orang tua. Dengan demikian, ibu akan mampu mengembangkan konsep diri dan karakter anak sesuai dengan harapan keluarga.

2) Konstruksi orang tua (ibu) tentang isolasi sosial yang harus dilakukan terhadap anak dalam upaya untuk melindungi anak dari polusi sosial.

Orang tua perlu memberi proteksi terhadap anak, terutama pada masa sosialisasi primer sehingga anak cukup kokoh untuk menghadapi perbedaan nilai dan mampu melindungi dirinya pada saat ia menghadapi dunia sosial di luar dunia yang diproteksi oleh orang tua. Proteksi diberikan dalam berbagai bentuk, termasuk isolasi sosial yang dilakukan pada masa sosialisasi prime. Isolasi sosial dilakukan dalam bentuk mendidik - home schooling atau hanya menitipkan anak pada orang terpercaya, memilihkan teman atau peer group bagi anak, menanamkan nilai-nilai dan transfer pengetahuan serta makna berbagai hal yang diyakini orang tua. Isolasi sosial dan proteksi secara bertahap akan dikurangi sesuai perkembangan fisik dan mental anak. Anak harus dapat mandiri dan melindungi diri sendiri sesuai dengan tata nilai yang dianut orang tua selambatlambatnya pada usia menjelang kuliah. 
Sosialisasi primer melalui isolasi sosial dan proteksi orang tua ini membutuhkan waktu lebih lama dibandingkan dengan proses yang sama yang terjadi pada anak-anak lain. Namun seluruh informan meyakini, setelah melewati tahap ini karakter anak akan lebih kokoh dan tidak mudah terpengaruh oleh nilai-nilai yang berbeda dengan keyakinannya.

3) Keyakinan orang tua (ibu) tentang kemampuan anak untuk beradaptasi dalam pergaulan sosial setelah anak menjadi lebih besar dan harus bergaul dalam masyarakat luas.

Pada masa sosialisasi primer, Ibu harus melakukan transfer pengetahuan kepada anak. Ibu juga harus menyampaikan makna dari semua pengetahuan dan nilainilai yang dianut oleh keluarga hingga anak memahami makna intersubjektif pengetahuan dan nilai-nilai keluarga tersebut secara kokoh atau terinternalisasi dalam dirinya. Keberhasilan sosialiasi primer dapat diuji melalui berbagai dialog dan proses pengambilan keputusan pada diri anak.

Setelah anak mencapai keyakinan yang cukup, secara bertahap anak memasuki masa sosialisasi sekunder. Pada saat itu secara bertahap orang tua mengurangi proteksi atau isolasi sosial yang dibuat dengan mengizinkan anak untuk bersosialisasi pada lingkungan di luar lingkungan sosial bentukan orang tua, seperti memilih teman sendiri atau memilih sekolah, serta mengambil berbagai keputusan penting untuk diri sendiri. Tahap sosialisasi sekunder tidak mudah diuji atau diukur keberhasilannya pada diri anak karena prosesnya sudah lebih kompleks dibandingkan dengan sosialisasi sekunder. Namun demikian, keberhasilan sosialisasi nilai-nilai keluarga pada masa sosialisasi primer akan menentukan keberhasilan sosialisasi sekunder sang anak, agar sesuai dengan harapan orang tua. Keberhasilan sosialisasi primer akan menumbuhkan keyakinan Ibu bahwa akan akan berhasil memasuki masa sosialisasi sekunder, sesuai harapan orang tua.

\section{DAFTAR PUSTAKA}

Berger, P. L., \& Luckmann, T. (2012).

Tafsir Sosial Atas Kenyataan. LP3ES.

Creswell, J. W. (1998). Qualitative

Inquiry and Research Design

Choosing Among Five

Tradition. Sage Publication.

Eriyanto. (2007). Analisis Framing :

Konstruksi, Ideologi, dan Politik

Media. LKIS.

Little, W. (2014). Introduction to

Sociology. OpenStax College. 
Macdonald, F. (2015, November 14).

Anak-anak yang dibesarkan

binatang. Dipetik Agustus 16,

2016, dari

http://www.bbc.com/indonesia/v

ert_cul/2015/11/151106_vert_cu

1_feral

Mulyana, D. (2003). Metodologi

Penelitian Kualitatif. Remaja

Rosdakarya.

Sobur, A. (2013). Filsafat Komunikasi.

Remaja Rosdakarya.

Zhao, S. (2005). The Digital Self :

Through the Looking Glass of

Telecopresent Others. Symbolic

Interaction. 

